\title{
New genus and species of Schizomyiina (Diptera, Cecidomyiidae) from Brazil
}

\author{
Barbara Proença ${ }^{1,2,4}$ \& Valéria Cid Maia ${ }^{1,3,5}$ \\ 1 Universidade Federal do Rio de Janeiro (UFRJ), Museu Nacional (MN), Departamento de Entomologia, \\ Laboratório de Diptera. Rio de Janeiro, RJ, Brasil. \\ 2 Universidade Federal do Rio de Janeiro (UFRJ), Museu Nacional (MN), Departamento de Entomologia, \\ Laboratório de Diptera Neotropicais, Volunteer researcher. Rio de Janeiro, RJ, Brasil. \\ ${ }^{3}$ Universidade Federal do Rio de Janeiro (UFRJ), Museu Nacional (MN), Departamento de Entomologia, \\ Laboratório de Diptera Neotropicais, Researcher and Professor. Rio de Janeiro, RJ, Brasil. \\ ${ }^{4}$ ORCID: http://orcid.org/0000-0001-8081-0676. E-mail: bproenca28@gmail.com \\ ${ }^{5}$ ORCID: http://orcid.org/0000-0001-9396-5618. E-mail: maiavcid@acd.ufrj.br
}

\begin{abstract}
A new gall midge genus, Distinctamyia gen. nov., and a new species Distinctamyia matogrossensis sp. nov. (Diptera, (ecidomyiidae) are herein described and illustrated (larvae, pupal exuviae, male and female). The new species induces conical, green, hairy and one chambered galls on leaf and bud of Simarouba amara Aubl. (Simaroubaceae). Gall-inducer specimens, samples of gall and host plant were collected at Parque Nacional da Chapada dos Guimarães, in the state of Mato Grosso (Midwestern Brazil).
\end{abstract}

Keywords. Asphondyliini; Cerrado; Gall midges; Morphology; Parque Nacional da Chapada dos Guimarães.

\section{INTRODUCTION}

The gall midges of the subtribe Schizomyiina (Asphondyliini) are characterized by adults without apical projection on the first tarsomere of each leg (except for some Schizomyia that may have a small spur), the male's gonostyli have unfused denticles, the females don't have large lobes at the posterior end of the eighth tergite, but occasionally may have a very small one, and the ovipositor is elongate and tapered. The pupa may or may not have prominent antennal bases and usually has projections on the frons, and only the anterior part of the third to eighth abdominal segments is covered by small cuticular spines. The larva may have six or fewer lateral papillae, and a ventral anus (Gagné, 1994; Gagné \& Jaschhof, 2021).

There are 157 species in 26 genera of Schizomyiina to the world and this group shows a great diversity outside the temperate Holarctic Region. Most of species occur on Neotropical area and only Schizomyia, the most diverse genus of the tribe, is cosmopolitan, with 56 species known so far (Gagné \& Jaschhof, 2021; Ospina-Peñuela et al., 2021).

Simarouba amara Aubl. (Simaroubaceae) occurs in the rainforests and savannas of South and Central America, and the Caribbean
(Franceschinelli et al., 1998). In Brazil, it is commonly known as "marupá", where it is found in the phytogeographical domains Amazon rainforest, Caatinga, Cerrado, and Atlantic Forest (Flora do Brasil, 2020). It is used in landscaping, reforestation areas, and in traditional medicine, to treat stomachache, hemorrhoids, dysentery and other diseases (Lorenzi, 1992; Sambuichi et al., 2009; Le Cointe, 1934).

Four leaf galls have been reported on this plant in Brazil: (1) cylindrical, green, and glabrous galls, collected at Porto de Trombetas, in Oriximiná municipality, Pará state (Northern Brazil) by Almada \& Fernandes (2011); (2) discoid, green and glabrous galls collected at Reserva Ecológica Carnijó, in Moreno municipality, Pernambuco state (Northeastern Brazil) by Santos et al. (2012); (3) globoid, green and glabrous galls collected at Reserva Biológica de Saltinho, in Rio Formoso and Tamandaré municipalities, Pernambuco state by Santos et al. (2012); and (4) conical, green and glabrous galls collected at Reserva Biológica da União, in Rio de Janeiro state (Southeastern Brazil) by Maia \& Siqueira (2020). The first three are induced by undetermined species of Cecidomyiidae (Diptera), while the gall-inducer of the last morphotype is still unknown.

Another gall morphotype was found by the authors in Parque Nacional da Chapada dos 


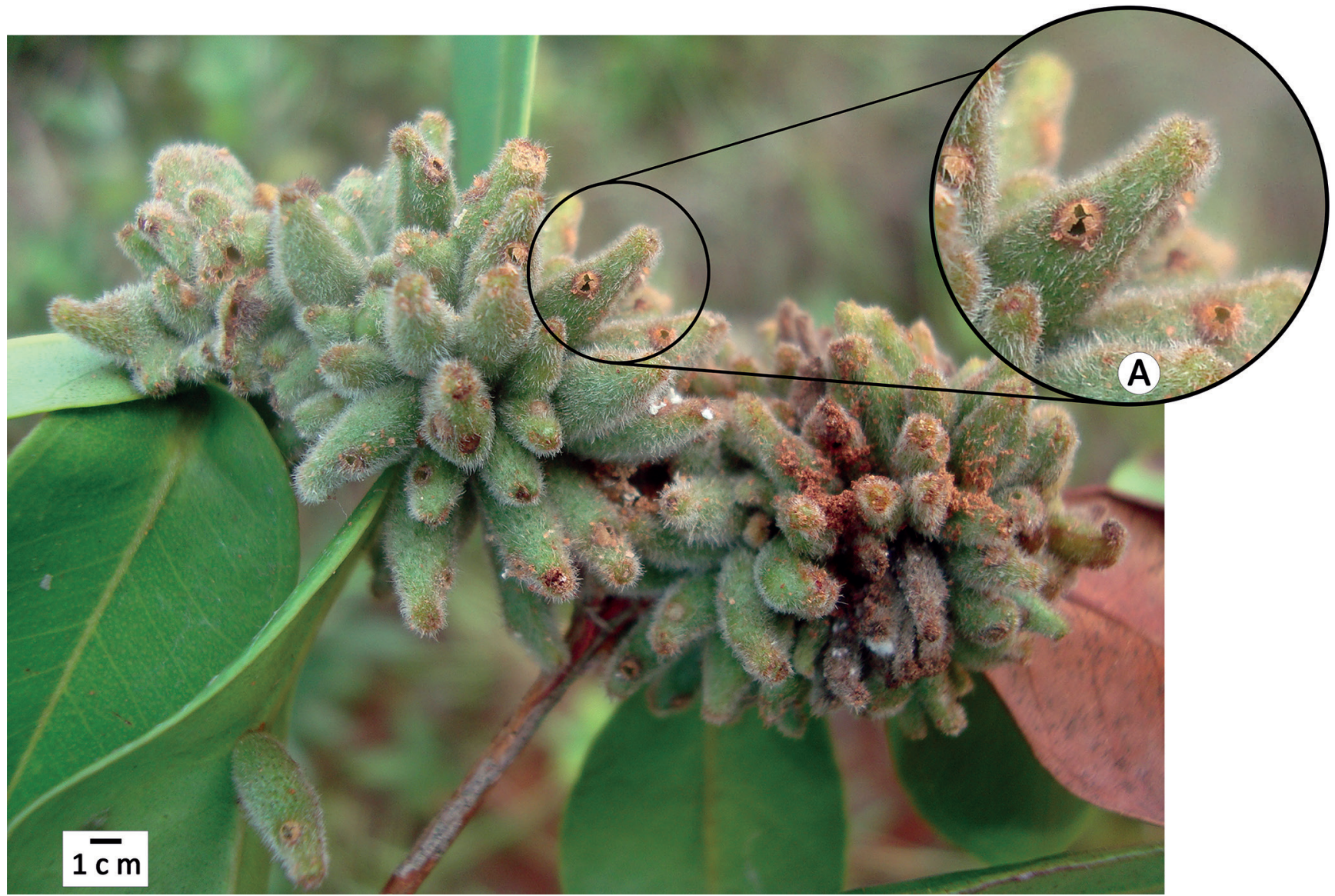

Figure 1. Conical, green, hairy and one-chambered galls induced by Distinctamyia matogrossensis Proença \& Maia (Diptera: Cecidomyiidae) on leaves and buds of Simarouba amara Aubl. (Simaroubaceae). (1) gall's detail.

Guimarães (National Park of Chapada dos Guimarães), located at Chapada and Cuiabá municipalities, in Mato Grosso state. It is conical, green, hairy, one chambered and occurs on leaves and buds of S. amara (Fig. 1). The inducer is a new gall midge species, which is described here.

\section{MATERIAL AND METHODS}

This study is part of the project "Diptera dos estados do Mato Grosso, Mato Grosso do Sul e Rondônia: diversidade, sistemática e limites distribucionais" (Diptera of the states of Mato Grosso, Mato Grosso do Sul and Rondônia: diversity, systematics and distributional limits). This project aimed at inventory the diversity of Diptera from Brazil's North and Midwest regions.

The species herein described was collected on January 2012 in Cidade das Pedras trail at Parque Nacional da Chapada dos Guimarães (National Park of Chapada dos Guimarães). This Park is located at Chapada and Cuiabá municipalities, in Cerrado (savanna) areas, in the state of Mato Grosso (Brazil). The gall (Fig. 1) was photographed using a digital camera and characterized by the plant organ of occurrence, shape, color, presence or absence of trichomes, and number of internal chambers.

Samples of galls and host plant were collected, labeled and transported to the Laboratório de Diptera Neotropicais (Museu Nacional/UFRJ, Rio de Janeiro), where part of the galls were placed in plastic pots cov- ered with fine screen at room temperature to rear adults. Other samples were dissected to obtain larvae and pupae of the inducer. All specimens were prepared and mounted on slides following the methods outlined in Gagné (1994).

We used the key to Neotropical genera of Gagné (1994) to identify this cecidomyiid, but it did not fit in any known genus. As other genera have been described since then, we examined the literature and compared this gall midge with others described after 1994. We recognized a new genus and species of Schizomyiina, which is described here.

Morphological studies were done using an optical microscope. Drawings were made with the aid of a drawing tube, and photographs were taken using a camera coupled to the microscope. All drawings were scanned and processed in Autodesk SketchBook 4+ and both plates and photographs were processed in Photoshop CS6 ${ }^{\circledR}$. Measurements were made using a microscope slide with scale from $0.01 \mathrm{~mm}$ to $5.0 \mathrm{~mm}$.

We designated a male as holotype and males, females, pupal exuviae and larvae as paratypes. All material, including the types, is deposited in the Cecidomyiidae collection of Museu Nacional, Rio de Janeiro (MNRJ). Morphological terminology follows Gagné (1994). The field work was done by Rodrigues, A.R., and the description of the new species by Proença, B. and Maia, V.C.

The host plant was identified by Dr. Gracialda Ferreira and Manuel Cordeiro from Universidade Federal Rural da 
Amazônia (UFRA) and the exsiccate was deposited in the herbarium of that institution.

\section{RESULTS}

\section{Distinctamyia gen. nov., Proença \& Maia}

Diagnose: Adult: Palpus 1 or 2-segmented. Males and females with irregular and reticulated circumfila. $R_{s}$ vestigial, $R_{5}$ slightly curved reaching $C$ just after the wing apex; CuA bifurcated. Tarsal claws simple, bent before its midlenght, empodia shorter than the bend in claws. Male cerci with deep triangular lobes, shorter than gonocoxites; parameres present. Ovipositor protrusible, female cerci fused. Pupa: antennal horns short and simple, frontal horns absent, prothoracic spiracle short, abdominal segments without dorsal spines. Larvae: spatula with two apical teeth, one pair of setose lateral papillae, one pair of terminal papillae with setae subequal in length.

Description: Adult head (Figs. 2-4): Eyes join one another at the vertex, antennae with 12 cylindrical flagellomeres, flagellomeres 1 and 2 not connate, circumfila reticulated in both sexes. Female with flagellomeres 1 and 12 shorter than rest. Palpus one or two-segmented. Thorax (Figs. 5-6): $\mathrm{R}_{1}$ reaching $C$ before wing midlength, $R_{s}$ and $S c$ absent, $R_{5}$ slightly bent reaching $C$ immediately before wing apex, $\mathrm{M}_{3}$ evanescent, CuA bifurcated (Fig. 5). First tarsomere of each leg without apical projection; tarsal claws simple, bent slightly before the midlength; empodia rudimentary (Fig. 6). Abdomen (Figs. 7 and 9): tergite 8 not sclerotized, without any vestiture, sternite 8 shorter than the others in males; tergite 8 sclerotized, narrower than rest and sternite 8 not sclerotized in females. Male terminalia (Fig. 8): cerci bilobed, hypoproct slightly bilobed, aedeagus wide, parameres present. Ovipositor (Fig. 10): soft, protrusible, gradually tapered to apex; cerci fused.

Pupal exuvia (Fig. 11): Antennal horns short, prothoracic spiracle short, abdominal segments without spines.

Larva (Figs. 15 and 16): spatula well sclerotized, with two apical teeth and shaft developed. One pair of lateral papillae with seta; one pair of terminal papillae with seta.

Type species: Distinctamyia matogrossensis sp. nov., Proença \& Maia.

\section{Distinctamyia matogrossensis sp. nov., Proença \& Maia}

Description: Adult: Body length: $1.80-2.70 \mathrm{~mm}$ in males $(n=4) ; 3.50-4.10 \mathrm{~mm}$ in females $(n=5)$. Head (Fig. 2): eyes join one another at the vertex, facets circular, all closely approximated; antenna $2+12$, scape obconical with 4-6 setae, 1.32 times longer than pedicel $(n=5)$; pedicel glo- bose with 4-6 setae $(n=5)$; male flagellomeres subequal in length, last female flagellomere shorter, with setae. Flagellomeres neck (Figs. 3 and 4) with a single row of setulae in male and bare in female, circumfila reticulated in both sexes. Frontoclypeus with 7-12 setae $(n=5)$. Labrum long, ending slightly after the hypopharynx, narrowed to apex, with two setae $(n=5)$. Hypopharynx triangular, setulose apically $(n=5)$. Labella with eight short mesal setae $(n=5)$. Palpus with one or two segments, claviform, second segment three times as long as the first one. Thorax (Fig. 5): wings 1.5-1.7 mm long in males $(n=6)$ and 2.1-2.6 mm long in females $(n=7)$. Scutum with two rows of dorsal setae, highly concentrated at the anterior margin, forming a double row up to the end of the scutum; no lateral rows. Scutelum bare; anepimeron with many setae. Other pleural sclerites bare. Legs (Fig. 6): tarsal claws simple, strongly sclerotized, bent slightly before its midlenght. Empodium setulose, short, not reaching bend in claws.

Male abdomen (Fig. 7): tergites and sternites rectangular with rounded margins. Trichoid sensillae absent. Tergites 1-7 sclerotized with complete posterior row of setae, sparse lateral setae and scales elsewhere. Tergite 8 not sclerotized, bare, appreciably shorter and narrower than tergite 7. Sternites 2-6 sclerotized, with setae more abundant at midlenght, many lateral setae, complete posterior row of setae, and elsewhere with scales. Sternites 7-8 sclerotized, covered with setae and scales. Sternite 8 shorter than other sternites.

Male terminalia (Fig. 8): gonocoxites triangular, robust, wider than long. Gonostylus semicircular, with setae and scales. Cerci with deep triangular lobes, with setae. Hypoproct narrow, triangular, setulose, rough basally, with slight reentrance in the middle at the apex, with two apical setae. Aedeagus wide, cylindrical. Parameres short, trapezoid with two apical setae.

Female abdomen (Fig. 9): Tergites and sternites without trichoid sensillae. Tergite 1-8 sclerotized, tergites 1-7 rectangular, tergite 1 with complete posterior row of setae, tergites 2-7 with rounded margins, complete posterior row of setae, scales elsewhere. Tergite 8 rectangular, with rounded margins, shorter than the others, with complete posterior row of setae and scales elsewhere. Sternites 2-7 sclerotized, rectangular, with setae more abundant at midlenght, several lateral setae, complete posterior row of setae and scales elsewhere. Sternite 8 not sclerotized, with a membranous area covered with spine-like projection of the tegument.

Ovipositor (Fig. 10): soft, protrusible, 1.26-1.75 times as long as sternite 7, striated at basal half, distal half with long ventral and dorsal setae and sclerotized ventrally. Cerci distinct, fused, with short setae apically.

Pupal exuvia (Figs. 11-14): Body length: $2.80-4.20 \mathrm{~mm}$ $(n=4)$. Sclerotized integument. Cephalic region (Fig. 11): Antennal horns short, 0.02-0.03 mm long $(n=6)$, simple, 

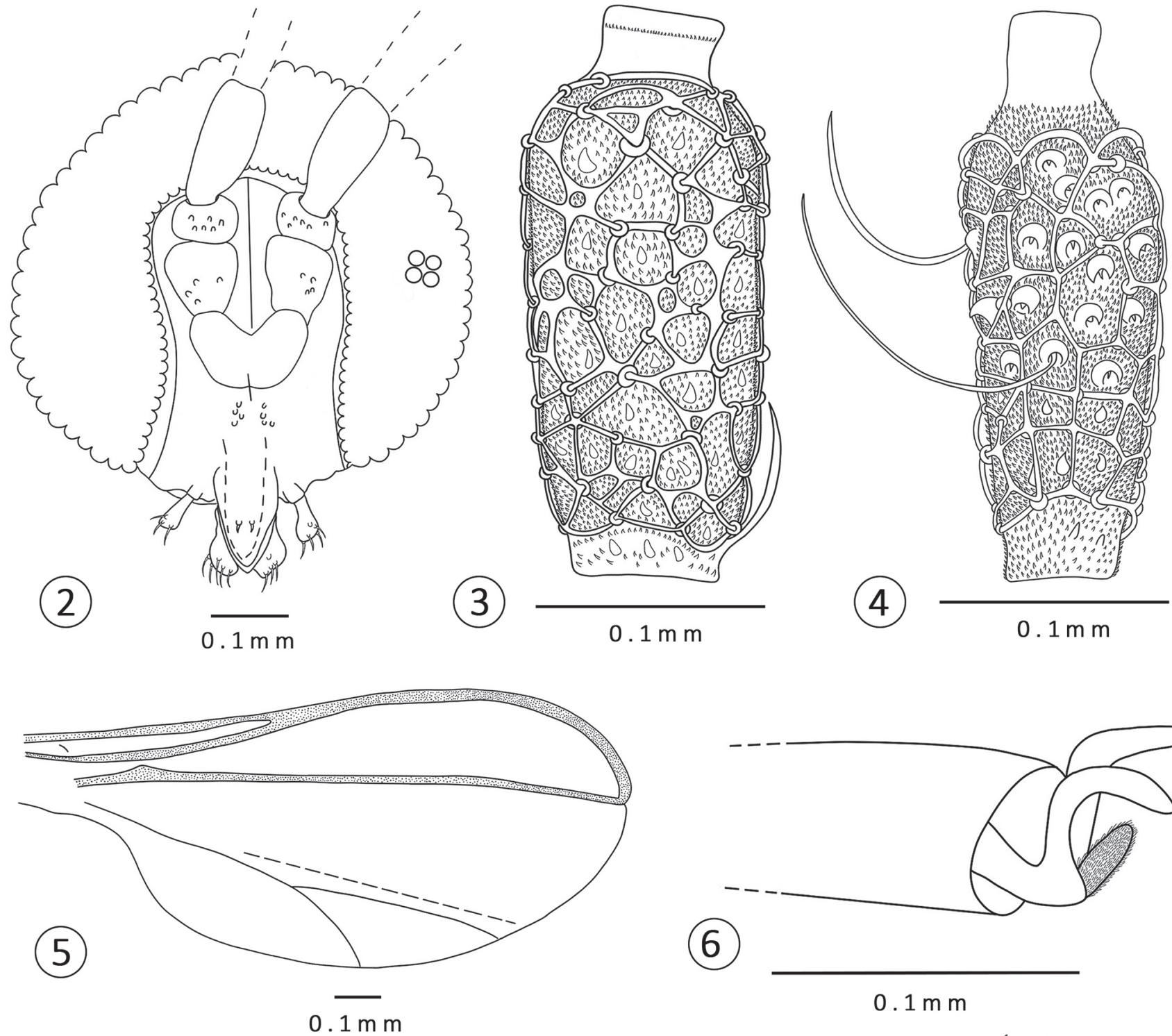

(6)
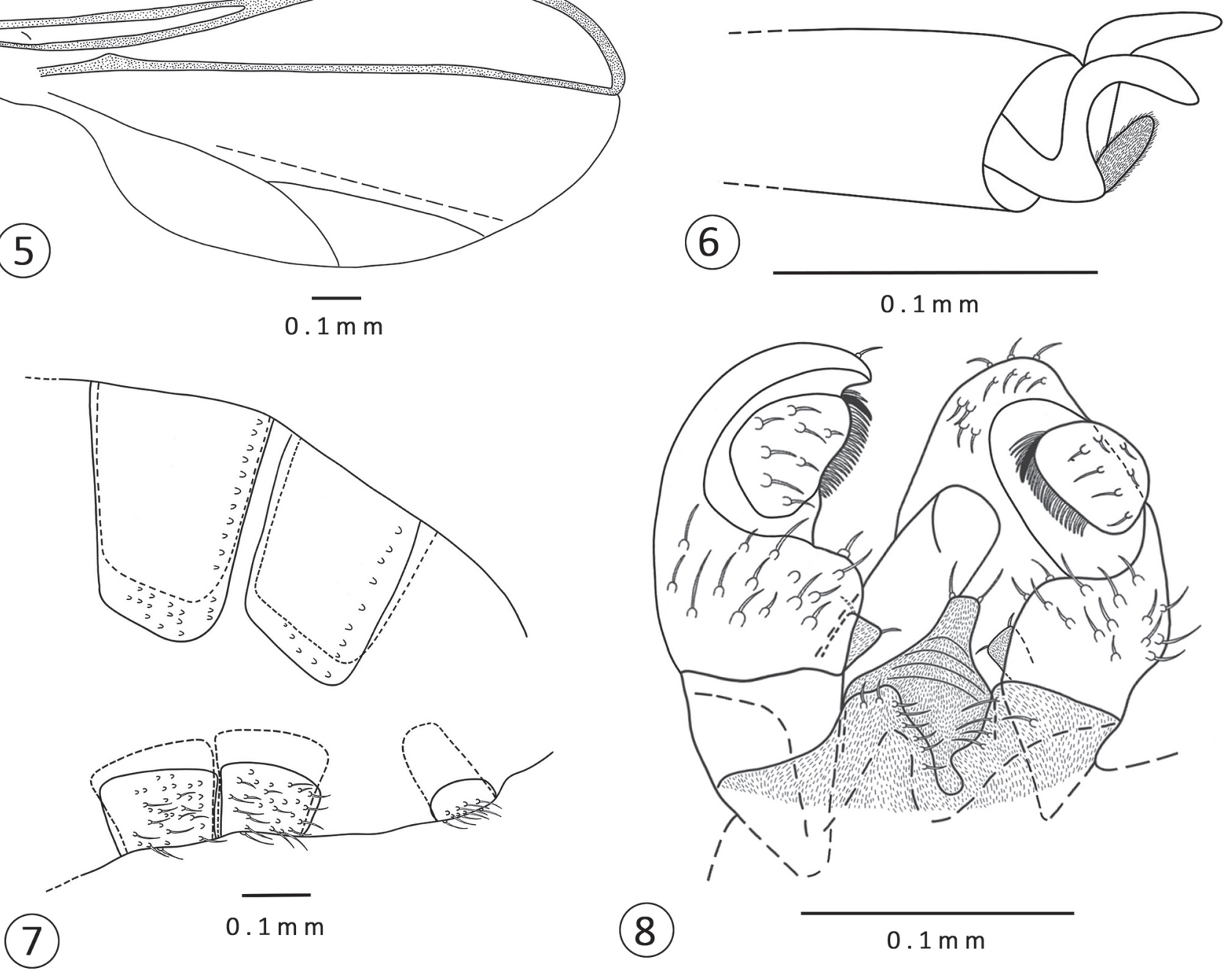

$0.1 \mathrm{~m} \mathrm{~m}$

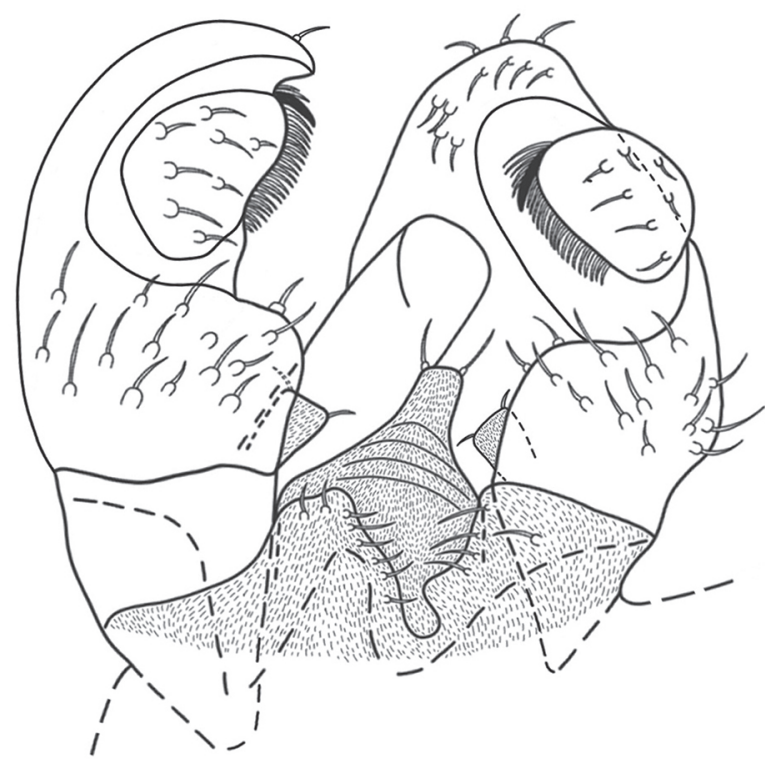

8

$0.1 \mathrm{~m} \mathrm{~m}$

Figures 2-8. Distinctamyia matogrossensis Proença \& Maia. (2) male head (frontal view) with 2-segmented palpus. In detail: one-segmented palpus; (3) male flagellomere V; (4) female flagellomere V; (5) male wing; (6) female hind leg: claws and empodium (lateral view); (7) male abdomen, segments 6-8 (lateral view); (8) male terminalia (dorsal view). 
triangular. Antennal sheath with 3-4 setae near antennal horns (Fig. 12). Upper cephalic margin thickened laterally. Cephalic region with rough tegument at the lower area, above the palpus sheath and above the labrum sheath. Apical papillae asetose; lateral and lower facial papillae not visible. Thorax (Fig. 11): Tegument rough along the ecdysial line. Prothoracic spiracle digitiform, short, 0.06-0.10 $\mathrm{mm}$ long $(\mathrm{N}=5)$. Wings sheath reaching midlength of abdominal segment III; forelegs sheath reaching midlength of abdominal segment $\mathrm{Vl}$; midlegs sheath reaching posterior margin of abdominal segment $\mathrm{Vl}_{\text {; }}$ hindlegs sheath reaching midlenght of abdominal seg-

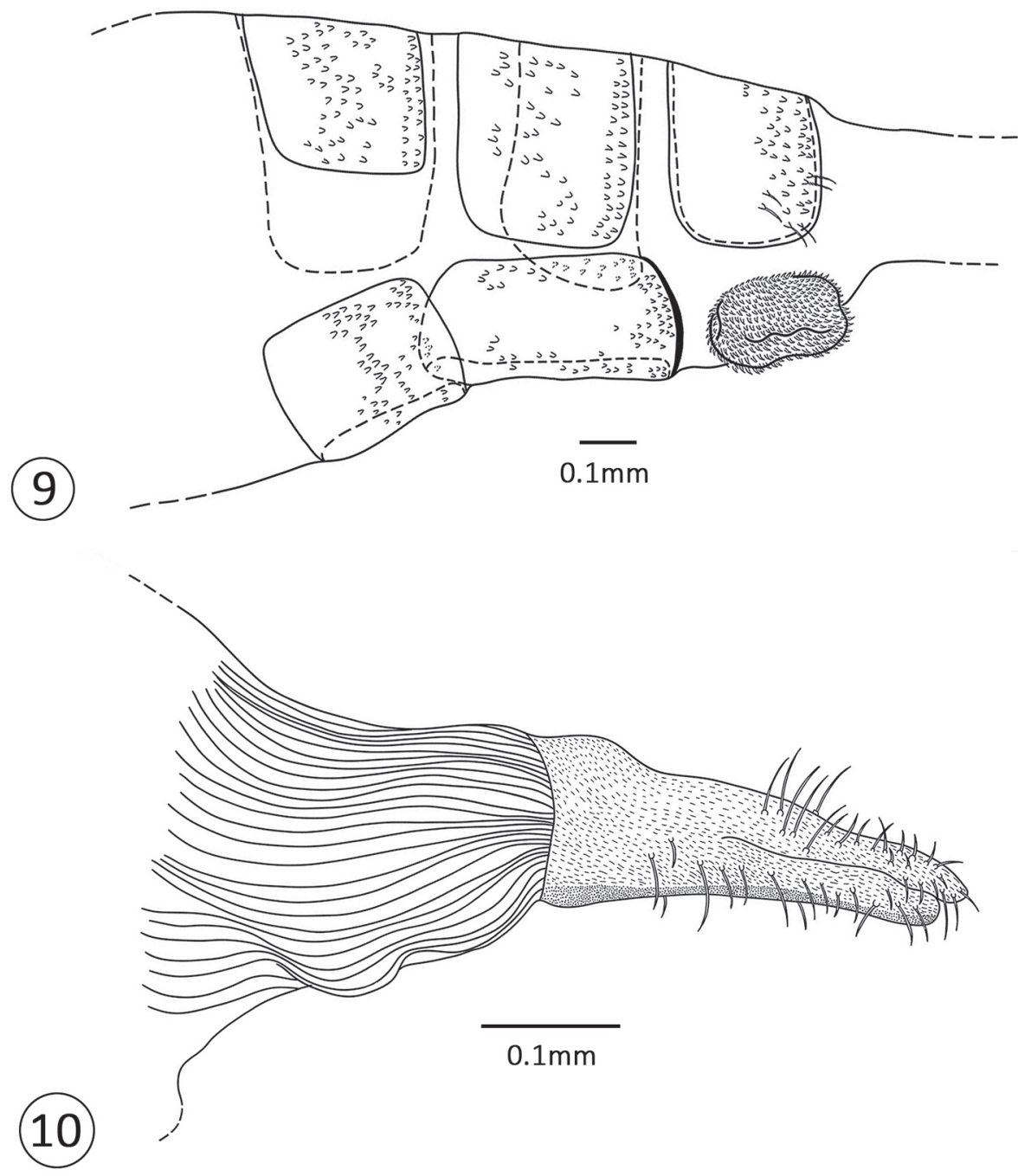

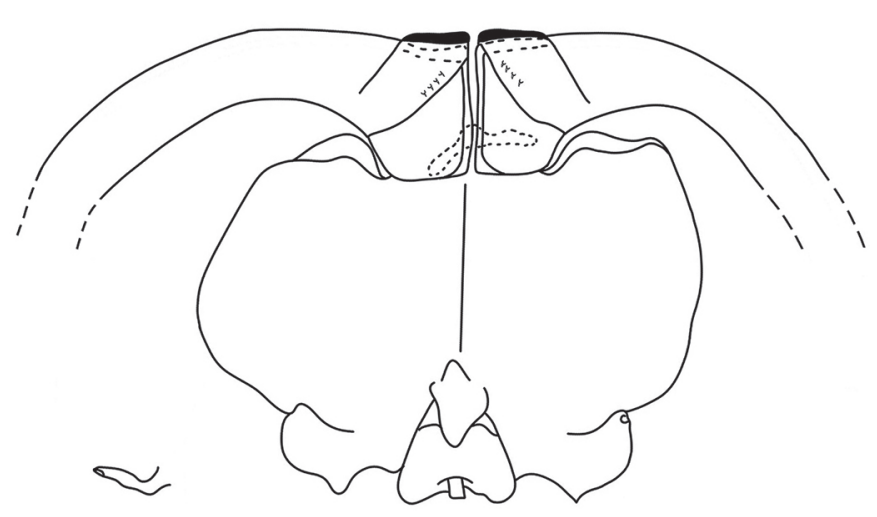

11

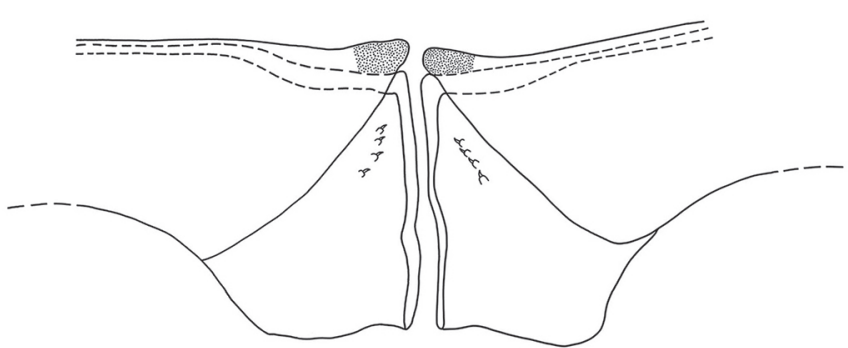

$0.1 \mathrm{~mm}$

Figures 9-12. Distinctamyia matogrossensis Proença \& Maia. (9) female abdomen, segments 6-8 (lateral view); (10) ovipositor (lateral view). In detail, female cerci dorsolateral view; (11) pupal exuviae: cephalic region and prothoracic spiracle (frontal view); (12) pupal exuviae: antennal horn. 

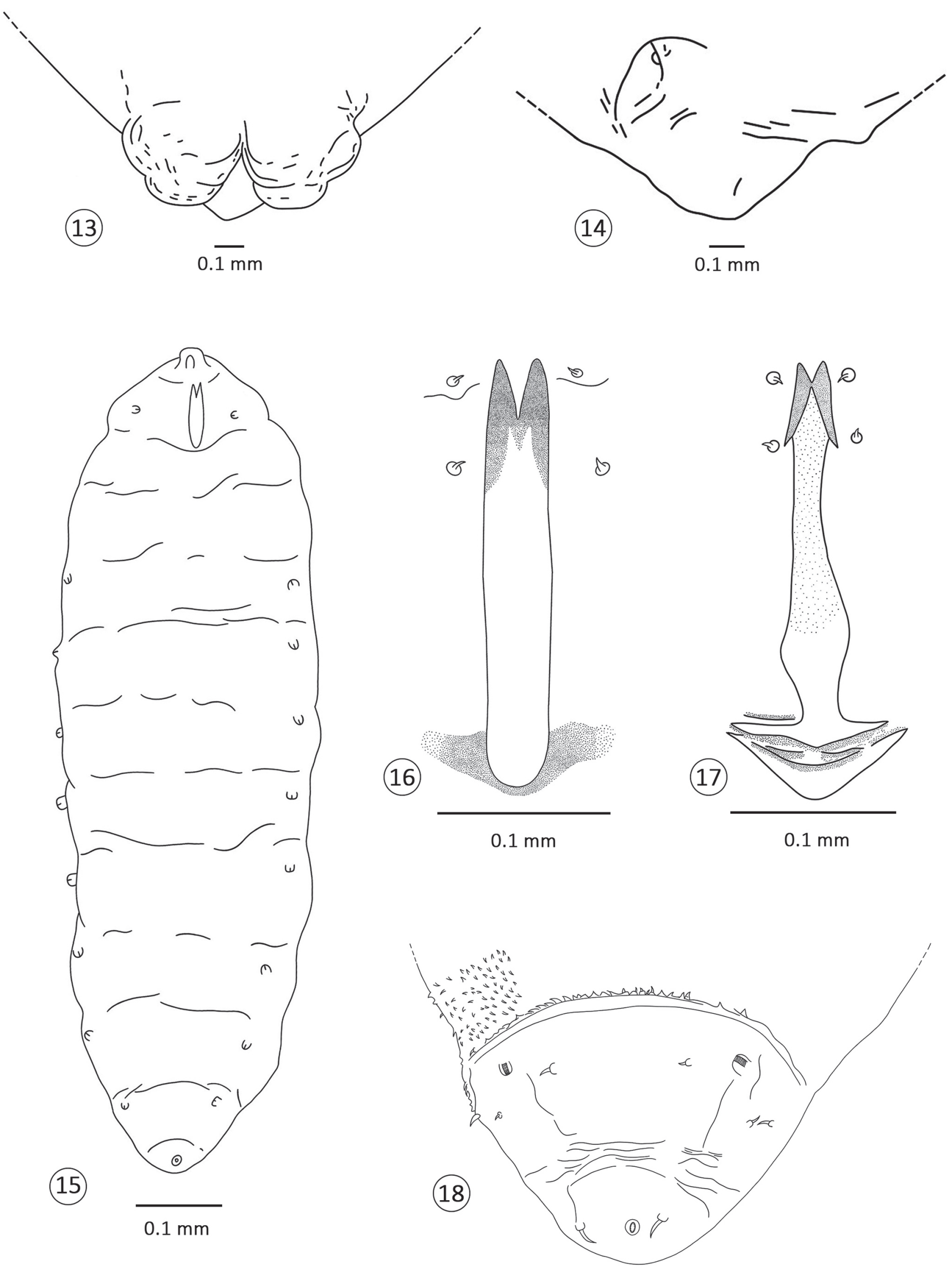

$0.1 \mathrm{~mm}$

Figures 13-18. Distinctamyia matogrossensis Proença \& Maia. (13-14) sexual dimorphism on pupal exuviae: (13) male's pupal exuvia: terminal segment (ventral view); (14) female's pupal exuvia: terminal segment (ventral view); (15) larva, general aspect (ventral view); (16-17) larval spatula: (16) truncated shaft and lateral papillae (ventral view); (17) shaft with basal lateral projections and lateral papillae (ventral view); (18) larva: terminal segments (ventral view). 
ment VII. Abdomen: Spiny integument, dorsally striated at the posterior margin. Dorsal spines absent. Terminal segment with two apical lobes only in male and female terminal segment rounded (Figs. 13 and 14).

Third instar larva (Figs. 15-18): Body length: 2.20-2.50 mm $(n=5)$. White, spiny integument, cylindrical body (Fig. 15). Sternal papillae setose. Spatula well sclerotized, 0.4-0.7 mm long, with two triangular teeth, approximate to each other. Spatula shaft long, truncate basally (shaft 4.5-5.7 times as long as teeth) (Fig. 16) or with two lateral projections resembling an anchor (shaft 7.0-8.3 times as long as teeth) (Fig. 17). One setose lateral papilla on each side. Terminal segment rounded, with a pair of terminal papillae, with setae subequal in length (Fig. 18).

Host plant: Simarouba amara Aubl. (Simaroubaceae).

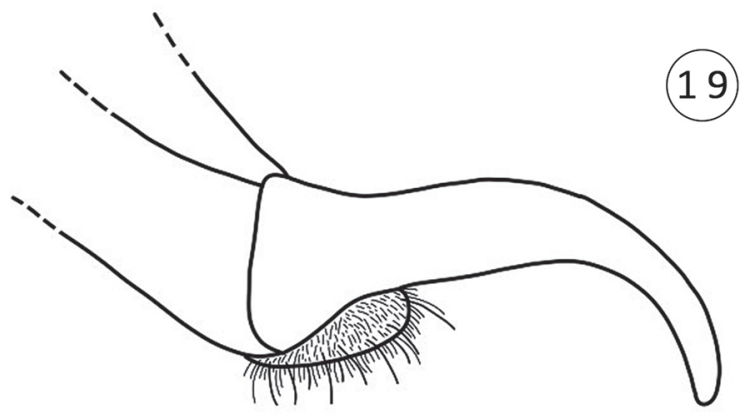

$0.02 \mathrm{~m} \mathrm{~m}$

Brethesiamyia myrciae Maia, 2010

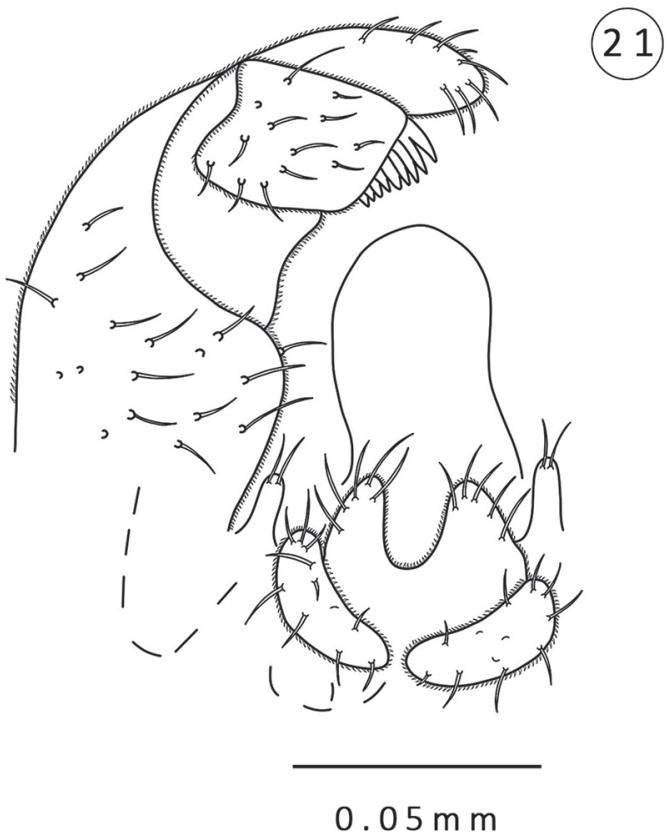

Brethesiamyia myrciae Maia, 2010
Gall (Fig. 1): on leaf and bud, conical, hairy, green and one chambered.

Etymology: The generic name is composed by two words: "distincta" and "myia". The former means "distinct" and the latter is a suffix frequently used to refer to midges and flies. The specific name, "matogrossensis", refers to the Brazilian state, Mato Grosso, where this species was collected.

Associated fauna: Parasitoid wasps (Hymenoptera: Eulophidae: Tetrastichinae) were obtained from the galls.

Material examined: Holotype: BRAZIL: $\sigma^{\pi}$ (7 flagellomeres, antennae broken, legs broken), Midwest Brazil, Mato Grosso state, Chapada dos Guimarães municipality, Parque Nacional da Chapada dos Guimarães, Cidade das

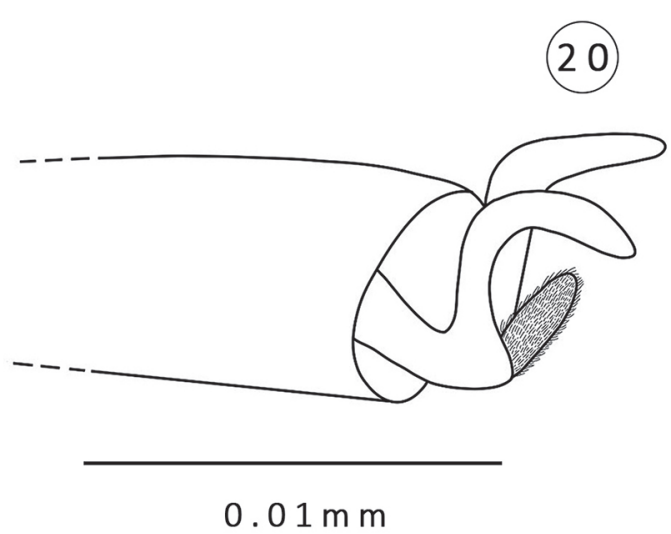

Distinctamyia matogrossensis Proença \& Maia sp. nov.

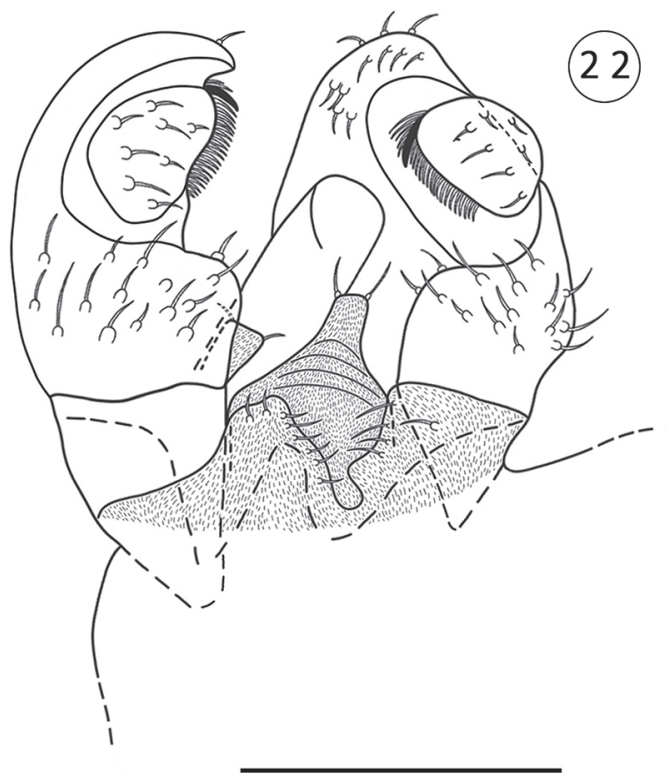

$0.01 \mathrm{~m} \mathrm{~m}$

Distinctamyia matogrossensis Proença \& Maia sp. nov.

Figures 19-22. (19) female midleg: tarsal claw and empodium of Brethesiamyia myrciae Maia, 2010; (20) female hind leg: claws and empodium (lateral view) of Distinctamyia matogrossensis Proença \& Maia; (21) male terminalia (dorsal view) of Brethesiamyia myrciae Maia, 2010; (22) male terminalia (dorsal view) of Distinctamyia matogrossensis Proença \& Maia. 


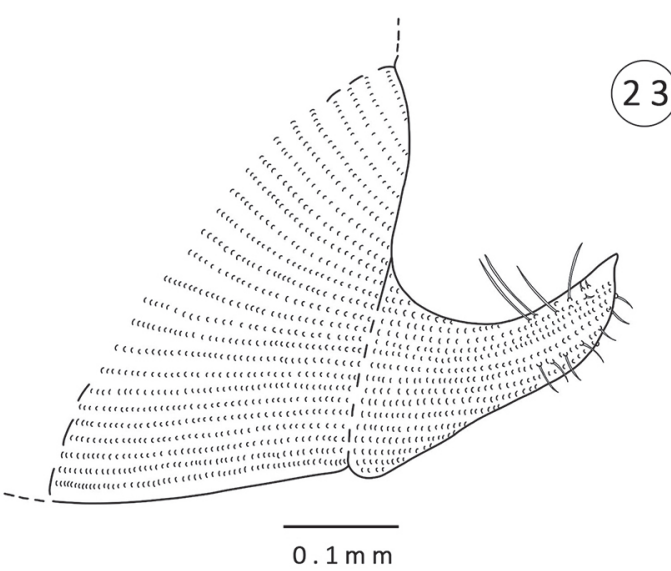

Brethesiamyia myrciae Maia, 2010

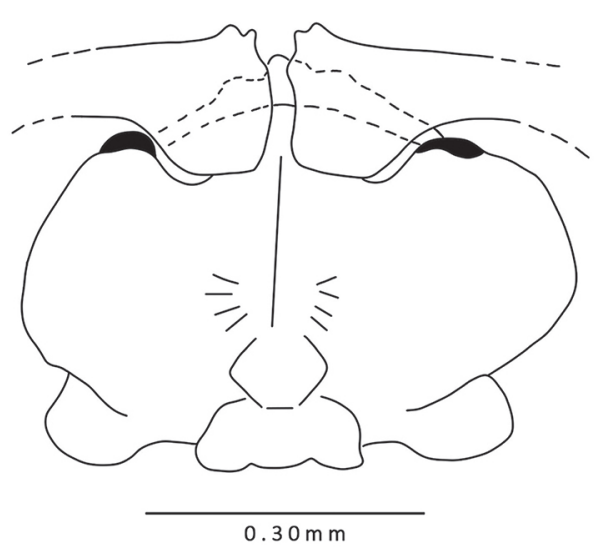

Brethesiamyia myrciae Maia, 2010

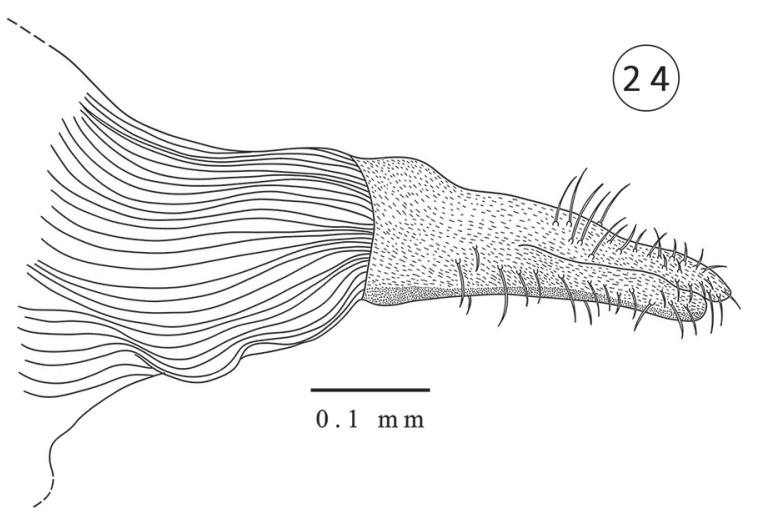

Distinctamyia matogrossensis Proença \& Maia sp. nov.

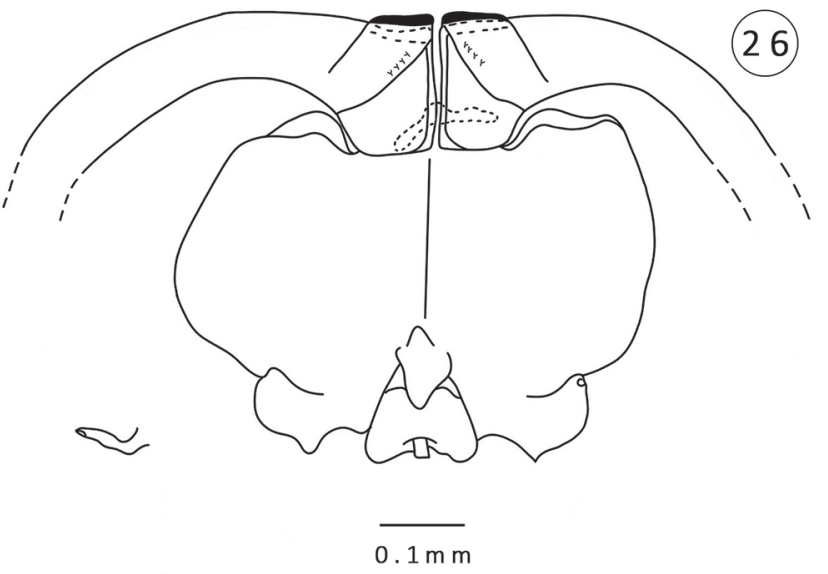

Distinctamyia matogrossensis Proença \& Maia sp. nov.

Figures 23-26. (23) ovipositor (lateral view) of Brethesiamyia myrciae Maia, 2010. In details female cerci (dorsal view); (24) ovipositor (lateral view) of Distinctamyia matogrossensis Proença \& Maia; (25) pupal head (frontal view) of Brethesiamyia myrciae Maia, 2010; (26) pupal exuviae: cephalic region and prothoracic spiracle (frontal view) of Distinctamyia matogrossensis Proença \& Maia.

Pedras trail, $15^{\circ} 25^{\prime} 40^{\prime \prime} \mathrm{S}, 55^{\circ} 49^{\prime} 59^{\prime \prime} \mathrm{W}, 16$ January 2012 Rodrigues col. Simarouba amara Aubl. (Simaroubaceae), (MNRJ). Paratypes: same locality, date and collector: 3 males, 6 females, 10 pupal exuviae, 8 pupae and 7 larvae. Additional material: 3 females, same locality, date and collector.

Type locality: Parque Nacional da Chapada dos Guimarães, Cidade das Pedras trail $\left(15^{\circ} 25^{\prime} 40^{\prime \prime} \mathrm{S}\right.$, $\left.55^{\circ} 49^{\prime} 59^{\prime \prime} \mathrm{W}\right)$, Chapada dos Guimarães municipality, Mato Grosso state, Brazil.

\section{DISCUSSION}

The new genus is included in Schizomyiina based on the following characters: first tarsomere without apical projection; gonostylus with denticules not fused, ovipositor soft, pupal exuviae with frontal horns absent. There are 26 described genera placed in Schizomyiina, 14 occurring in Brazil. The new genus, Distinctamyia, presents female and male circumfila, adult's palpi and pupae similar to those of Brethesiamyia Maia, 2010. However, the two genera differ in the following characteristics: tarsal

Table 1. Comparative table of morphological features of adults, pupal exuvia and larva of Distinctamyia Proença \& Maia gen. nov., Brethesiamyia Maia, 2010, Bruggmannia Tavares, 1906, Proasphondylia Felt, 1915 and Stephomyia Tavares, 1916.

\begin{tabular}{|c|c|c|c|c|c|c|c|c|c|c|}
\hline \multirow[b]{2}{*}{ Genera } & \multicolumn{4}{|c|}{ Adult } & \multicolumn{5}{|c|}{ Pupal exuvia } & \multirow{2}{*}{$\begin{array}{c}\text { Larva } \\
\text { Spatula }\end{array}$} \\
\hline & Palpi & $\begin{array}{c}\text { Male } \\
\text { circumfila }\end{array}$ & $\begin{array}{c}\text { Male } \\
\text { hypoproct }\end{array}$ & $\begin{array}{l}\text { Female } \\
\text { cerci }\end{array}$ & $\begin{array}{c}\text { Antennal } \\
\text { bases }\end{array}$ & Facial papillae & $\begin{array}{c}\text { Upper frontal } \\
\text { spines }\end{array}$ & $\begin{array}{l}\text { Prothoracic } \\
\text { spiracle }\end{array}$ & $\begin{array}{l}\text { Dorsal } \\
\text { spines }\end{array}$ & \\
\hline Distinctamyia Proença \& Maia gen. nov. & One or two-segmented & Reticulated & Slightly bilobed & Fused & Present & Absent & Absent & Short & Absent & Present \\
\hline Brethesiamyia Maia, 2010 & One-segmented & Reticulated & Deeply bilobed & Separate & Present & Absent & Absent & Short & Absent & Present \\
\hline Bruggmannia Tavares, 1906 & Three-segmented & Not reticulated & Deeply bilobed & Separate & Present & Present & Generally present & Spot-like or short & Present & Absent \\
\hline Proasphondylia Felt, 1915 & Three-segmented & Not reticulated & Deeply bilobed & Separate & Absent & Present & Present & Spot-like & Present & Absent \\
\hline Stephomyia Tavares, 1916 & One-segmented & Sinuous & Slightly bilobed & Fused & Present & Generally present & Absent & Short & Absent & Present \\
\hline
\end{tabular}


claws curved beyond midlength and empodia rudimentary in Brethesiamyia (Fig. 19), but in Distinctamyia the tarsal claws are bent before its midlenght and the empodia are shorter, not rudimentary (Fig. 20); male hypoproct deeply bilobed in Brethesiamyia (Fig. 21) and slightly bilobed in Distinctamyia (Fig. 22); female cerci separated in Brethesiamyia (Fig. 23) and fused in Distinctamyia (Fig. 24); antennal horn bifid in Brethesiamyia (Fig. 25) and simple and triangular in Distinctamyia (Fig. 25).

In Table 1 is shown a comparison between the morphological features of adults, pupal exuvia and larva of the new genera with those of Brethesiamyia Maia, 2010; Bruggmannia Tavares, 1906; Proasphondylia Felt, 1915 and Stephomyia Tavares, 1916.

\section{ACKNOWLEDGMENTS}

We thank to Msc. Alene Ramos Rodrigues for the field work and all researchers of the Sisbiota Diptera project. The Sisbiota Diptera project was supported by CNPq (Conselho Nacional de Desenvolvimento Científico e Tecnológico), process 563256/2010-9 and FAPESP (Fundação de Amparo à Pesquisa do Estado de São Paulo), process 2010/52314-0. We are also grateful to the following institutions for their financial support to their researches: $\mathrm{BP}$ to Coordenação de Aperfeiçoamento de Pessoal de Nível Superior (CAPES) for the PhD scholarship and VCM to Conselho Nacional de Desenvolvimento Científico e Tecnológico (CNPq), process 301481/2017-2.

\section{AUTHORS' CONTRIBUTIONS}

Barbara Proença: Writing, editing and drawing. Valéria Cid Maia: Supervision, writing, review and editing. All the authors actively participated in the discussion of the results, they reviewed and approved the final version of the paper.

\section{REFERENCES}

Almada, E.D. \& Fernandes, G.W.A. 2011. Gall-inducing insects in terra firme forest and reforested areas in eastern Amazon, Pará, Brazil. Boletim do Museu Paraense Emílio Goeldi. Ciências Naturais, 6(2): 163-196.

Flora do Brasil. 2020. [em construção]. Jardim Botânico do Rio de Janeiro. Available: http://floradobrasil.jbri.gov.br. Access: 20/07/2020.

Franceschinelli, E.V.; Yamamoto, K. \& Source, G.J.S. 1998. Distinctions among three Simarouba species. Systematic Botany, 23(4): 479-488.

Gagné, R.J. 1994. The Gall Midges of the neotropical region. Ithaca, N.Y., Cornell University Press.

Gagné, R.J. \& Jaschhof, M. 2021. A catalog of the Cecidomyiidae (Diptera) of the world. 5. ed. Digital. Available: https://www.ars.usda.gov/ ARSUserFiles/80420580/Gagne Jaschhof 2021 World Cat 5th Ed.pdf.

Le Cointe, P. 1934. Árvores e plantas úteis (indígenas e aclimatadas). Belém, Livraria Clássica, Amazônia Brasileira.

Lorenzi, H. 1992. Árvores brasileiras: manual de identificação e cultivo de plantas arbóreas nativas do Brasil. Nova Odessa, Plantarum.

Maia, V.C. \& Siqueira, E.S. 2020. Insect galls of the Reserva Biológica União, Rio de Janeiro, Brazil. Biota Neotropica, 20(1): e20190758. DOl

Ospina-Peñuela, E.A.; Lamas, C.J.E.; Serna, F. \& Urso-Guimarães, M.V. 2020. A new species of Brethesiamyia Maia (Diptera: Cecidomyiidae) from Colombia with description of immature forms. Papéis Avulsos de Zoologia, 60: e20206066. https://www.revistas.usp.br/paz/article/view/173773.

Sambuichi, R.H.R.; Silva, L.A.M.; Jesus, M.F.C. de \& Paixão, J.L. da. 2009. Lista de ávores nativas do sul da Bahia. In: Sambuichi, R.H.R.; Mielke, M.S. \& Pereira, C.E. Nossas árvores: conservação, uso e manejo de árvores nativas no sul da Bahia. Editus. Ilhéus, Universidade Estadual de Santa Cruz. p. 171-257.

Santos, J.C.; Almeida-Cortez, J.S. \& Fernandes, G.W. 2012. Gall-inducing insects from Atlantic forest of Pernambuco, Northeastern Brazil. Biota Neotropica, 12(3): 198-213. D0I 